Nig. J. Biotech. Vol. 36 (2) : 127-138 (Dec 2019)

ISSN: 01891731

Available online at

http://www.ajol.info/index.php/njb/index

and www.biotechsocietynigeria.org

DOI: https://dx.doi.org/10.4314/njb.v36i2.13

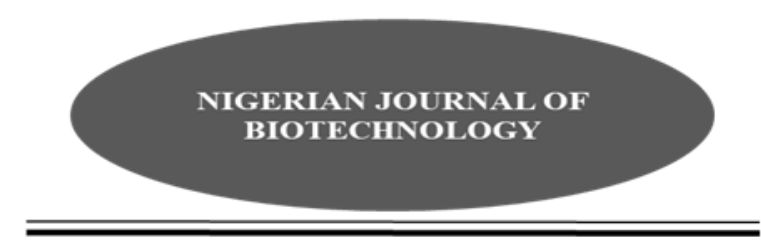

\title{
Isolation and identification of phytase-producing Bacillus and Enterobacter species from Nigerian soils
}

\author{
Onawola, 0. 0., ${ }^{1,2 *}$ Akande, I. S., ${ }^{1}$ Okunowo, W. 0.1 \\ and Osuntoki, A. A. ${ }^{1}$ \\ ${ }^{1}$ Department of Biochemistry, College of Medicine, University of Lagos, PMB 12003, Lagos, \\ Nigeria \\ ${ }^{2}$ Department of Biotechnology, Federal Institute of Industrial Research Oshodi, PMB 21023 \\ Ikeja, Lagos, Nigeria.
}

\begin{abstract}
The bioavailability of phosphorus and other nutrients in feed for monogastrics is restricted by the presence of phytate. Exogenous supply of phytase produced by bacteria and other microbes can enhance the bioavailability of these nutrients and reduce phosphorus pollution. The objective of the study was to isolate bacteria with phytase-producing potentials from soil; which may be employed for the bioavailability of phosphorus and other nutrients in feed for monogastrics in Nigeria. Top soil samples were collected from two dumpsites in Lagos, Nigeria and bacteria were isolated and screened for potentials to produce phytase. The isolates with phytase potential were primarily identified by their cultural and biochemical characteristics and then confirmed using the 16S rRNA sequencing, after which their expressed phytases were quantified. A total of six isolates belonging to three species were identified as phytase producers. Sequence data analyses revealed these to be Bacillus subtilis (2), Bacillus amyloliquefaciens (3) and Enterobacter cloacae (1) with accession numbers MH879827 and MH879832; MH879828, MH879830 and MH879831; and MH879829 respectively. Phenotypic phytase activity was highest in $E$. cloacae ODS $29(9.69 \pm 0.04 \mathrm{U} / \mathrm{ml})$ and least in B. subtilis ODS $10(8.83 \pm 0.02 \mathrm{U} / \mathrm{ml})$. In conclusion, phytase-producing Bacillus and Enterobacter species were isolated and characterized from Nigerian soils. These bacteria species could be used in biotechnological applications.
\end{abstract}

Keywords: Bacillus, Enterobacter, Monogastrics, Phylogenetic analysis, Phytase

*Corresponding authors E-mail: toyeine@yahoo.com,

\section{Introduction}

Legumes, oil seed crops and cereals serve as major sources of nutrients for humans and animals but they contain phytic acid; an antinutrient, which is the major storage form of phosphorous and other minerals in plants tissues, accounting for approximately $70-80 \%$ of the total phosphorous (Blaabjerg et. al., 2011). Phytate chelates phosphorus and other minerals, and also binds starch and proteins making them non bioavailable. Monogastric animals are unable to produce the requisite enzyme, phytase needed for the hydrolysis of phytate and as such cannot utilize these nutrients. This leads to nutrient deficiencies and can interfere with growth performance of animals. To alleviate nutrient deficiencies, animal feed is supplemented with phosphorus sources often in excess and this together with undigested phytate in feed can cause a high fecal phosphorus load in areas of intensive livestock production, resulting into environmental phosphorus pollution. As such, the enzymatic hydrolysis of phytate into inorganic phosphates and divalent cations in the intestine of monogastric animals is most desirable. Phytases catalyse the breakdown of phytic acid complexes to improve the nutritional value of feed and decrease the amount of phosphorous excreted. Naves et. al. (2014), Kumar et. al. (2015) and Abdel-Megeed and Tahir (2015) amongst others have reported the effectiveness of supplemental microbial 
phytases in improving utilization of phosphate from phytate. Phytases can be derived from a host of sources including plants, animals and microorganisms; however, the production of phytase from microbial origin is of great potential in developments. Currently, phytaseproducing microorganisms include yeasts such as Pichia anomala (Vohra et. al., 2010), molds such as Aspergillus ficcum (Zhang et. al., 2010), members of the genus Bacillus obtained from different soil sources viz; $B$. subtilis from Syrian soil (Abd-Alhadi et. al., 2015) and Bacillus species from an abattoir soil (Onawola et. al., 2016a) as well as from a host of other bacteria. Towards improving the nutritional value of plant-based feed for monogastric animals, reduction of environmental phosphorus pollution in areas of intensive livestock farming and reduction of cost incurred by farmers in Nigeria due to use of imported phytase, this study was aimed to isolate and characterize phytase-producing bacteria which could be employed in the production of phytase for use in animal feed in Nigeria.

\section{Materials and methods}

\section{Collection of Soil Samples}

A total of six (6) top soil samples were each obtained from the dumpsites of Olusosun, Ojota and the Federal Institute of Industrial Research Oshodi, (FIIRO) Lagos, Nigeria respectively. A sample of top soil was aseptically taken from each sampling point on the two locations using sterile spatulas and transferred into sterile screw cap bottles. These were capped tightly and transferred into a clean and dry plastic bucket that was sterilized on site using $70 \%$ ethanol and conveyed to the laboratory. All samples from each location were aseptically pooled together and mixed to obtain the composite sample for each dumpsite.

\section{Isolation and Screening for Phytase-Producing Bacteria}

This was carried out as described by Demirkan et. al. (2014) and Onawola et. al. (2016a) on $1 \mathrm{~g}$ each of composite soil sample obtained from each dumpsite. One gram each of composite samples was aseptically weighed and transferred into $9 \mathrm{ml}$ of sterile distilled water in screw cap test tubes and were regarded as the stock suspensions. These were capped tightly and contents mixed by gently turning the bottles up and down. One milliliter of each of the stock suspension was serially diluted in sterile distilled water up to the $4^{\text {th }}$ dilution. One hundred microlitre of the 4th dilutions were each spread-plated on nutrient agar plates and the plates incubated at 35 to $37^{\circ} \mathrm{C}$ for 24 hours (h). Based on morphological differences, bacteria colonies were aseptically picked out and sub cultured repeatedly on nutrient agar plates until pure and thereafter preserved on Luria Bertani agar slants. A loopful of each isolate was cultured overnight in $10 \mathrm{ml}$ of tryptone soya broth and $100 \mu \mathrm{l}$ each were aseptically inoculated into correspondingly labeled agar wells on sterile phytase specific medium (PSM) comprising ( $\mathrm{g} / \mathrm{L}$ ): Glucose 15.0; $\mathrm{NH}_{4} \mathrm{NO}_{3} \quad 5.0 ; \quad \mathrm{KCI} \quad 0.5 ; \quad \mathrm{MgSO}_{4} .7 \mathrm{H}_{2} \mathrm{O} \quad 0.5 ;$ $\mathrm{FeSO}_{4} .7 \mathrm{H}_{2} \mathrm{O} 0.01 ; \mathrm{MnSO}_{4} .4 \mathrm{H}_{2} \mathrm{O} 0.01$; calcium phytate (Sigma-Aldrich) 0.5; Agar 15.0; pH 5.5 and incubated at $37^{\circ} \mathrm{C}$ for $72 \mathrm{~h}$ without inversion. The development of a colony surrounded by a clear zone was considered a potential to produce phytase and the zone diameters were measured using a ruler and reported in millimeters. Bacterial isolates from Olusosun dumpsite were coded ODS with arabic numerals while isolates from FIIRO dumpsite were coded FDS with arabic numerals.

\section{Phenotypic Identification and Biochemical Characterization of Phytase-Producing Isolates}

Phenotypic identification was carried out as described by Holt et. al. (1994) while determination of the carbohydrate fermentation profile was carried out using the Analytical Profile Index (API) $50 \mathrm{CHB} / 20 \mathrm{E}$ (for Bacillus) and API $20 \mathrm{E}$ (for Enterobacter) kits of Biomereux according to manufacturer's instruction.

\section{Amplification and Sequence Determinations of the 16S rRNA Genes of the Bacterial Isolates}

Genomic DNA was extracted from each isolate and purified using the DNA isolation kit Quick DNA $^{\mathrm{TM}}$ (Zymo Research, USA). Isolation of the 16S rRNA genes was carried out using the primers: 27F: 5'- AGAGTT TGATCC TGG CTC AG $-3^{\prime}, \mathrm{T}^{\mathrm{M}} 58^{\circ} \mathrm{C}$ and 1492R: $5^{\prime}$ - GGTTAC CTT GTT ACG ACT $T T-3^{\prime}, T^{M} 53^{\circ} \mathrm{C}$ and the One Taq ${ }^{\circledR}$ Quick load SM0486S master mix as source of all dNTPs and polymerizing enzyme. PCR mixtures contained per assay: $12.5 \mu \mathrm{l}(1 \mathrm{X})$ of master mix, $0.5 \mu$ l of each primer $(0.24 \mathrm{mM}), 5 \mu \mathrm{l}$ of DNA (template), $6.5 \mu \mathrm{l}$ of sterile DNAse-free water. PCR profile of 30 minutes consisted of 30 cycles, each of $30 \mathrm{~s}$ (initial and final) denaturation at $94^{\circ} \mathrm{C}, 45 \mathrm{~s}$ annealing at $51^{\circ} \mathrm{C}$ and 1 and 5 min (initial and final) primer 
extension at $68^{\circ} \mathrm{C}$ respectively. A negative control was included and PCR products were analyzed on $1.5 \%$ agarose gel and purified. Nucleotide sequences were determined by the Sanger's method on the ABI $3130 \mathrm{XL}$ genetic analyzer system.

\section{Generic Identification of Phytase-Producing Isolates and Evolutionary Relationship}

Comparison of the six partial 16S rRNA gene sequences to the Genbank database was done using the BlastN program available at http://www.ncbi.nlm.nih.gov. All organisms used for the analyses were phytase-producing bacteria and their sequences were of reference sequence (RefSeq) on the database. Cluster analysis was performed and model for the analysis was computed as described by Tamura et. al. (2013). Evolutionary history was inferred as described by Kimura (1980) and Felsenstein (1985). The bootstrap consensus tree inferred from 500 replicates was taken to represent the evolutionary history of the taxa analyzed and initial tree(s) for the heuristic search were obtained by applying the Neighbor-Join and BioNJ algorithms. A discrete Gamma distribution was used to model evolutionary rate differences among sites [ 5 categories $(+G$, parameter $=1.1455)$ ]. The analysis involved 22 nucleotide sequences and evolutionary analyses were conducted in MEGA6.

\section{Phytase Production and Estimation of Phytase Activities}

This was carried out as described by Saribuga et. al. (2014) and Onawola et al. (2016b) but with slight modification. One hundred microlitre of a washed suspension of an overnight culture of each phytase-producing bacteria in tryptone soya broth were aseptically inoculated into $50 \mathrm{ml}$ of correspondingly labeled sterile phytase production medium (PPM) broths comprising (g/L): Glucose 15.0; $\mathrm{NH}_{4} \mathrm{NO}_{3}$ 5.0; $\mathrm{KCI} 0.5$; $\mathrm{MgSO}_{4} .7 \mathrm{H}_{2} \mathrm{O} \quad 0.5 ; \quad \mathrm{FeSO}_{4} .7 \mathrm{H}_{2} \mathrm{O} \quad 0.01$; $\mathrm{MnSO}_{4} .4 \mathrm{H}_{2} \mathrm{O} \quad 0.01$; sodium phytate (SigmaAldrich) 5.0 for phytase production; pH 5.5 and thereafter incubated at $37^{\circ} \mathrm{C}$ for $72 \mathrm{~h}$ with shaking at $180 \mathrm{rpm}$. The activities of the expressed phytases were quantified by reacting $100 \mu \mathrm{l}$ of clear filtrate (the enzyme solution) with $200 \mu$ l of buffered substrate $(1.5 \mathrm{mM}$ sodium phytate in $0.2 \mathrm{M}$ sodium acetate, $\mathrm{pH}$
5.5) and incubated at $37^{\circ} \mathrm{C}$ for $15 \mathrm{~min}$. Reaction was terminated with $300 \mu$ l of trichloro acetic acid (TCA) and $400 \mu \mathrm{l}$ of ammonium molybdate reagent. The absorbance of the clear solutions were determined at $700 \mathrm{~nm}$ against a reference blank which contained distilled water in place of enzyme solution and amounts of inorganic phosphate liberated were calculated from a standard curve of $1 \mu \mathrm{mol} / \mathrm{ml}$ to $10 \mu \mathrm{mol} / \mathrm{ml}$ orthophosphate from dipotassium hydrogen phosphate. One unit of phytase activity $(\mathrm{U} / \mathrm{ml})$ was defined as the amount of phytase which liberated I $\mu \mathrm{mol}$ of orthophosphate from phytate per minute under the assay conditions. Isolates which had significantly higher phytase activities over the others were considered to be phytase hyper-producers.

\section{Statistical Data Processing}

Data obtained were analyzed by the One-way Analysis of Variance using the statistical package for the social sciences (SPSS) of IBM Corporation. Results were expressed as Mean \pm SEM and significant differences were evaluated using the Tukey HSD at $p \leq 0.05$.

\section{Results}

A total of fifty three bacterial isolates were obtained with four (4) and two (2) strains having potential to produce phytase from the Olusosun and FIIRO dumpsites, translating to about $12 \%$ and $10.5 \%$ respectively. Comparison of the partial 16S rRNA gene sequences of the isolates to the Genbank database revealed all isolates except ODS 29 to show high similarities to the RefSeq for the genus Bacillus with ODS 25, ODS 33 and FDS 10 having $99 \%$ identity to $B$. amyloliquefaciens and ODS 10 and FDS 16 having $99 \%$ identity to B. subtilis. Phylogenetic relations of ODS 25, ODS 33, FDS 10 and FDS 16 showed closest homology with $B$. amyloliquefaciens DSM 7 (NC 014551.1) while that of ODS 10 revealed closest homology to $B$. subtilis subsp. subtilis. The comparison of the partial 16S rRNA gene sequence of ODS 29 showed $99 \%$ similarity to the RefSeq for $E$. cloacae and closest phylogenetic homology with E. cloacae subsp. cloacae. Cluster and Neighbor-joining phylogenetic analyses revealed all six isolates to be grouped in three clusters. 


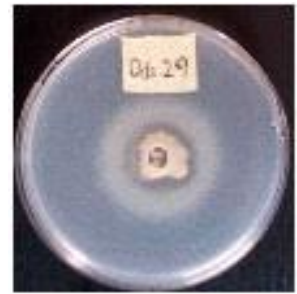

ODS 29

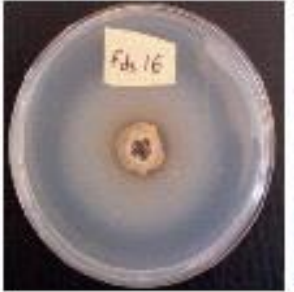

FDS 16

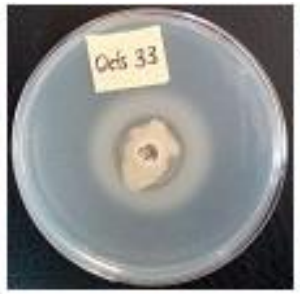

ODS 33

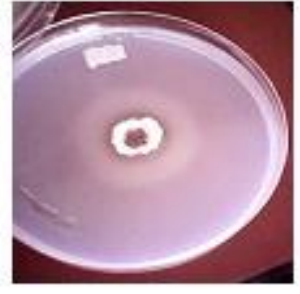

FDS 10

Figure 1. Clear zone formation by some phytase-producing bacteria.

Table 1: Zone diameter by phytase-producing bacteria after 72 hours of incubation

\begin{tabular}{ll}
\hline Isolate code & Zone diameter $(\mathbf{m m})$ \\
\hline ODS 10 & 25.0 \\
ODS 25 & 26.0 \\
ODS 29 & 32.0 \\
ODS 33 & 31.1 \\
FDS 10 & 29.0 \\
FDS 16 & 28.0 \\
\hline
\end{tabular}

Table 2: Phenotypic and structural characteristics of the phytase-producing bacteria species.

\begin{tabular}{|c|c|c|c|c|c|c|c|c|c|c|}
\hline IC & Cs & Col & Margin & Elevation & Shape & Tx & $\mathrm{Cm}$ & Mot & Gr & Ti \\
\hline $\begin{array}{l}\text { ODS } \\
10\end{array}$ & $\begin{array}{l}\text { Sm- } \\
\text { all }\end{array}$ & $\begin{array}{l}\text { Off- } \\
\text { white }\end{array}$ & Entire & Raised & Circular & Ns & Rods & Motile & + & Bacillus \\
\hline $\begin{array}{l}\text { ODS } \\
25\end{array}$ & Big & Cream & Undulate & Umbonate & Irregular & $S$ & Rods & Motile & + & Bacillus \\
\hline $\begin{array}{l}\text { ODS } \\
29\end{array}$ & $\begin{array}{l}\text { Sm- } \\
\text { all }\end{array}$ & $\begin{array}{l}\text { Cream/ } \\
\text { Iride- } \\
\text { scent }\end{array}$ & Serrated & Flat & Circular & Ns & Rods & Motile & - & $\begin{array}{l}\text { Entero- } \\
\text { bacter }\end{array}$ \\
\hline $\begin{array}{l}\text { ODS } \\
33\end{array}$ & Big & Cream & Entire & Umbonate & Irregular & $S$ & Rods & Motile & + & Bacillus \\
\hline $\begin{array}{l}\text { FDS } \\
10\end{array}$ & Big & Cream & Undulate & Umbonate & Irregular & $S$ & Rods & Motile & + & Bacillus \\
\hline $\begin{array}{l}\text { FDS } \\
16\end{array}$ & $\begin{array}{l}\text { Sm- } \\
\text { all }\end{array}$ & $\begin{array}{l}\text { Off- } \\
\text { white }\end{array}$ & Undulate & Raised & Irregular & Ns & Rods & Motile & + & Bacillus \\
\hline
\end{tabular}

Ic, Isolate code; Cs; Colony size; Col, Colour; Tx, Texture; $\mathbf{C m}$, Cellular morphology; Mot, Motility; Gr, Gram reaction; Ti, Tentative identity; Ns, non-slimy; S, slimy; +, positive; -, negative 
Table 3: Biochemical characteristics of the phytase-producing bacteria species

\begin{tabular}{|c|c|c|c|c|c|c|}
\hline Isolate code & ODS 10 & ODS 25 & ODS 29 & ODS 33 & FDS 10 & FDS 16 \\
\hline \multicolumn{7}{|l|}{ Biochemical } \\
\hline \multicolumn{7}{|l|}{ Tests } \\
\hline Oxidase & + & + & - & + & + & + \\
\hline Catalase & + & + & + & + & + & + \\
\hline ONPG & + & + & + & + & + & + \\
\hline $\mathrm{ADH}$ & - & - & + & - & - & - \\
\hline LDC & - & - & - & - & - & - \\
\hline ODC & - & - & + & - & - & - \\
\hline CIT & + & + & + & + & + & + \\
\hline $\mathrm{H}_{2} \mathrm{~S}$ & - & - & - & - & - & - \\
\hline URE & - & - & - & - & - & - \\
\hline TDA & - & - & - & - & - & - \\
\hline IND & - & - & - & - & - & - \\
\hline VP & + & + & + & + & + & + \\
\hline GEL & + & + & - & + & + & + \\
\hline GLU & - & + & + & + & + & + \\
\hline NIT & + & + & + & + & + & + \\
\hline $\mathrm{N}_{2}$ & & & - & & & \\
\hline MOB & & & + & & & \\
\hline $\mathrm{McC}$ & & & + & & & \\
\hline OF-O & & & + & & & \\
\hline OF-F & & & + & & & \\
\hline
\end{tabular}


Table 4: Carbohydrate fermentation profile of the phytase-producing bacteria species

\begin{tabular}{|c|c|c|c|c|c|c|}
\hline Isolate code $\Longrightarrow$ & ODS 10 & ODS 25 & ODS 29 & ODS 33 & FDS 10 & FDS 16 \\
\hline $\begin{array}{l}\text { Acid production from c } \\
\text { Control }\end{array}$ & hydrates: & - & - & - & - & - \\
\hline Glycerol & + & + & - & + & + & + \\
\hline Erythritol & - & - & - & - & - & - \\
\hline D-Arabinose & - & - & - & - & - & - \\
\hline L-Arabinose & + & + & + & + & + & + \\
\hline D-Ribose & + & + & - & + & + & + \\
\hline D-Xylose & + & + & - & + & + & + \\
\hline L-Xylose & - & - & - & - & - & - \\
\hline D-Adonitol & - & - & - & - & - & - \\
\hline MDX & - & - & - & - & - & - \\
\hline D-Galactose & - & - & - & - & - & - \\
\hline D-Glucose & + & + & - & + & + & + \\
\hline D-Fructose & + & + & + & + & + & + \\
\hline D-Manose & + & + & - & + & + & + \\
\hline L-Sorbose & - & - & - & - & - & - \\
\hline L-Rhamnose & - & - & + & - & - & - \\
\hline Dulcitol & - & - & - & - & - & - \\
\hline Inositol & + & + & - & + & + & + \\
\hline D-Manitol & + & + & + & + & + & + \\
\hline D-Sorbitol & + & + & + & + & + & + \\
\hline MDM & - & - & - & - & - & - \\
\hline MDG & + & + & - & + & + & + \\
\hline NAG & - & + & - & + & + & + \\
\hline Amygdalim & + & + & + & + & + & + \\
\hline Arbutin & + & + & - & + & + & + \\
\hline Esculin Ferric Citrate & + & + & - & + & + & + \\
\hline Salicin & + & + & - & + & + & + \\
\hline D-Celibiose & + & + & - & + & + & + \\
\hline D-Maltose & + & + & - & + & + & + \\
\hline
\end{tabular}


D-Lactose

D-Melibiose

D-Saccharose (sucrose)

D-Trehalose

Inulin

D-Melezitose

D-Raffinose

Amicon (starch)

Glycogen

Xylitol

Gentiobiose

D-Turanose

D - Lyxose

D - Tagatose

D - Fucose

$L$ - Fucose

D - Arabitol

$\mathrm{L}$ - Arabitol

Potassium gluconate

Potassium - 2 - ketogluconate

Potassium - 5 - ketogluconate

+ , positive reaction; $\quad-$, negative reaction; $\quad$ w, weakly positive

Presumptive isolates: ODS 10 and FDS 16, Bacillus subtilis, ODS 25, ODS 33 and FDS 10, Bacillus amyloliquefaciens, ODS 29, Enterobacter cloacae 


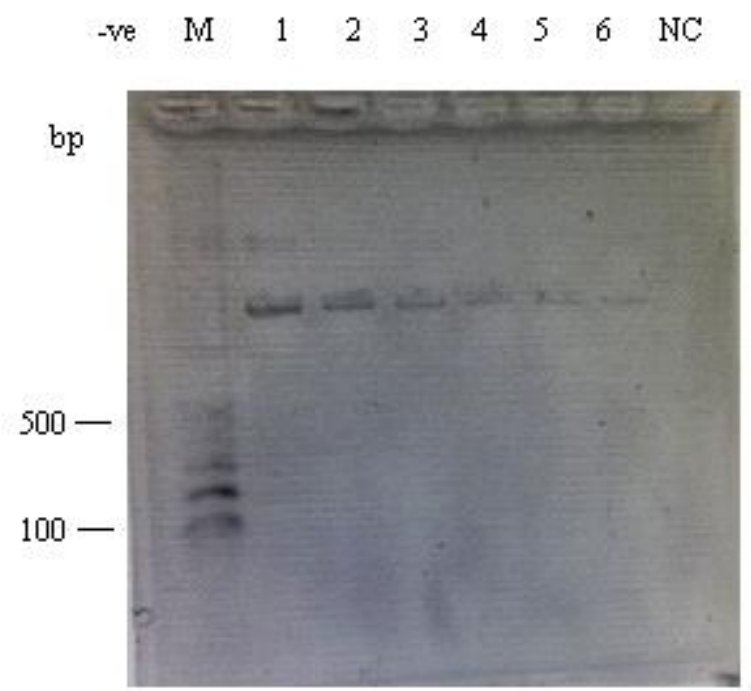

M, DNA ladder; NC, negative control; -ve, negative terminal. Lanes 1 to $6=$ ODS 29, ODS 33, FDS 16 , ODS 25, ODS 10 and FDS 10 respectively

Figure 2: Gel analyses of the amplified 16S rRNA genes of the six phytase-producing bacteria.

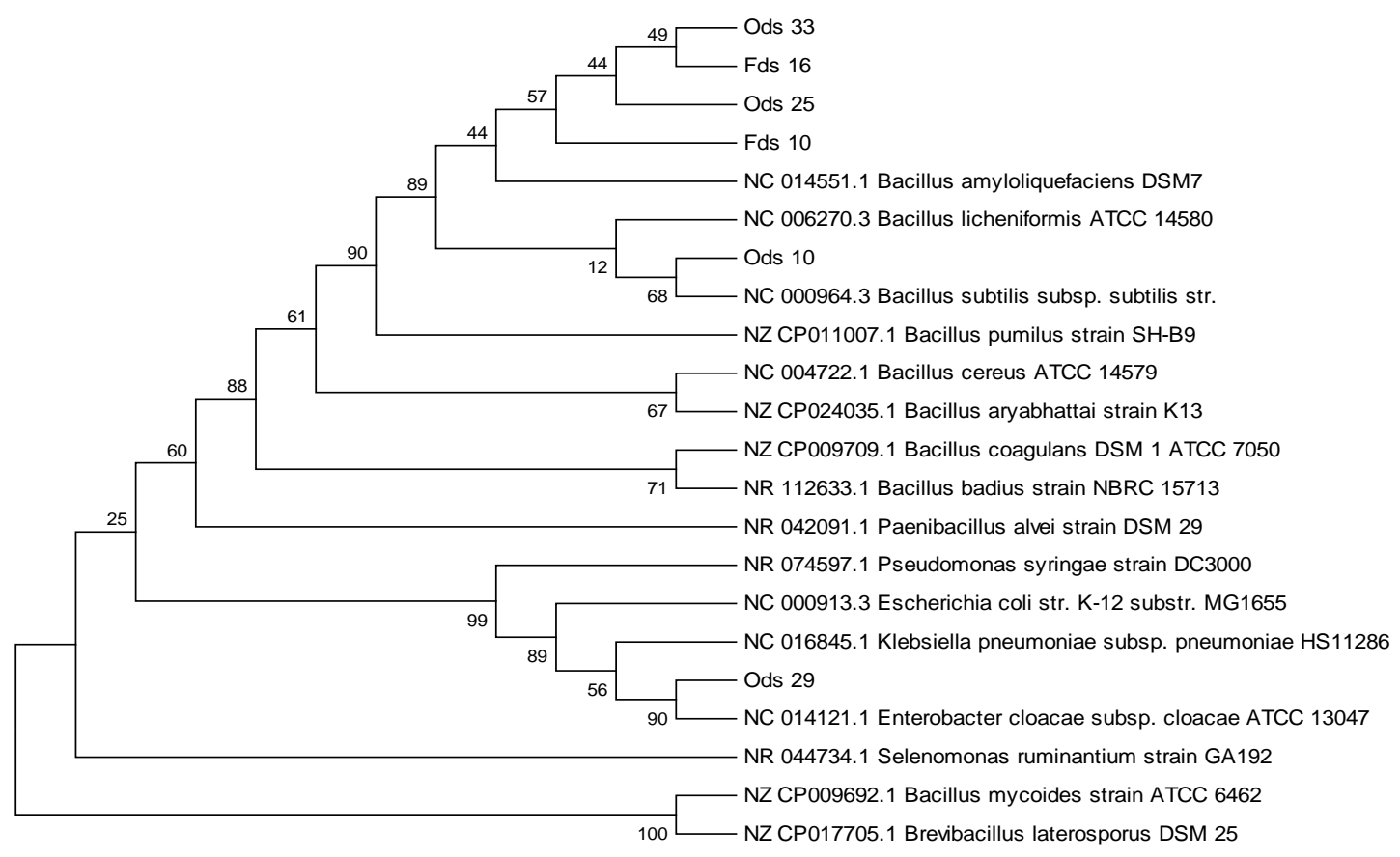

Figure 3: Phylogenetic relations of the phytase-producing bacteria with closely related RefSeq phytaseproducing bacteria strains. ODS 25 , ODS 33, FDS 10 and FDS 16 are more closely related to $B$. amyloliquefaciens DSM 7, while ODS 10 and ODS 29 are more closely related to $B$ subtilis subsp. subtilis and $E$. cloacae subsp. cloacae respectively. Similarity and homology of the neighboring sequences are shown by bootstrap values greater than $50 \%$. 


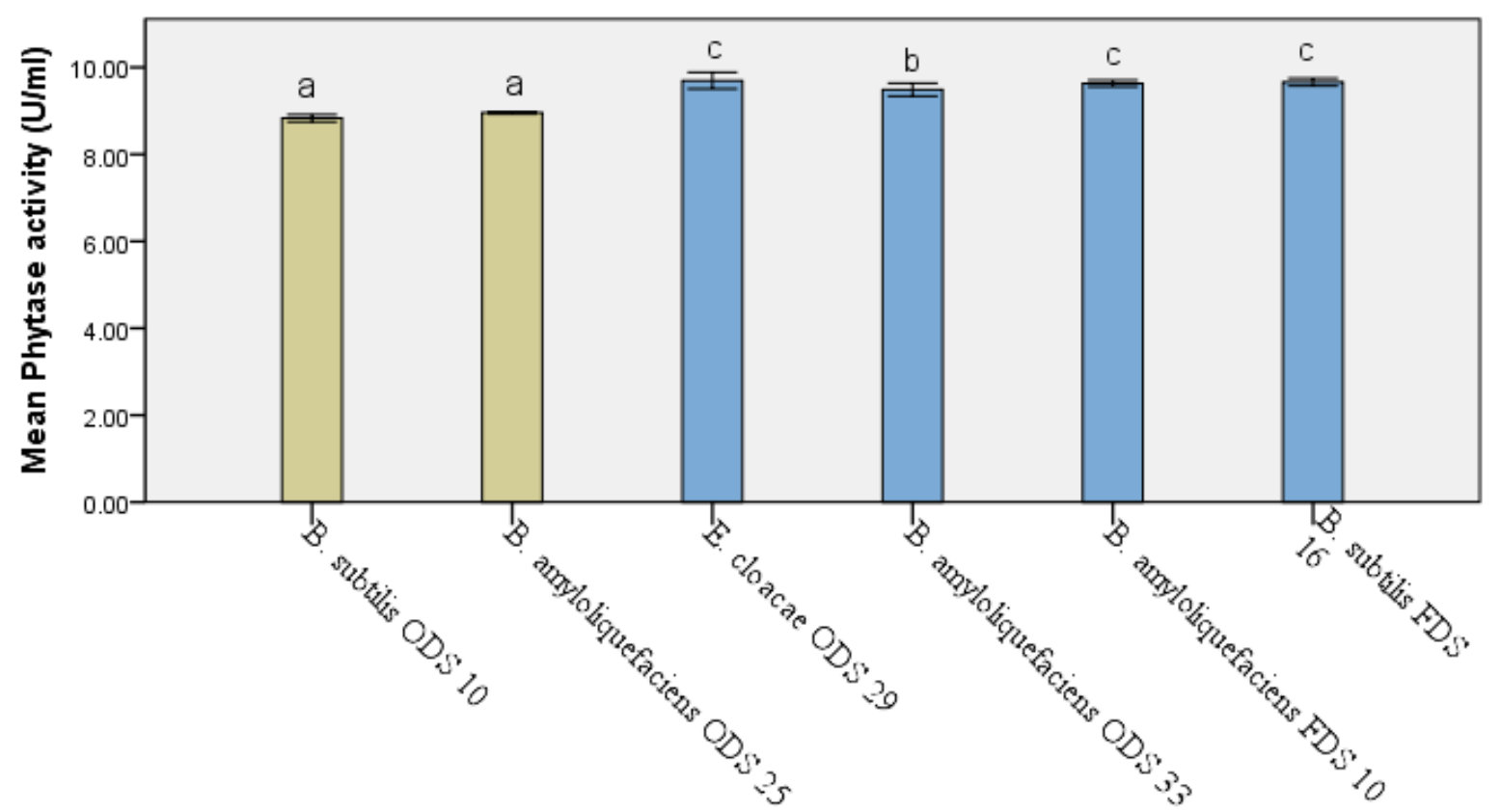

Bacteria isolates

Figure 4. Phytase activities of bacteria and selection of hyper-producing strains. Result shows E. cloacae ODS 29, B. amyloliquefaciens ODS 33 and FDS 10, and B. subtilis FDS 16 to be hyper-producers of phytase. Any two means not followed by the same letter are significantly different.

\section{Discussion}

Clear zone or halo formation by bacteria isolates on phytase specific medium is an indication of a potential to produce phytase, the enzyme required for the solubilization of phytate. The observation of clear zones surrounding the colonies of some of the isolates (Figure 1) agrees with the findings of Demirkan et. al. (2014), Abd-Alhadi et. al. (2015) and Onawola et. al. (2016b) who had isolated phytase-producing bacteria strains from the soil respectively. Phytase production by these isolates could be attributed to the possession of phytase-encoding genes in the DNA of the organisms, without which the enzyme cannot be synthesized. The observed phenotypic and structural characteristics of the isolates (Table 2) collectively satisfied the criteria for the genus Bacillus and E. cloacae as given by Bergey's manual of determinative bacteriology (Holt et. al. 1994) and agree with the findings of Logan and Vos (2009) for B. amyloliquefaciens and $B$. subtilis; and Brenner and Farmer (2001) for $E$. cloacae respectively. The differences observed in the phenotypic and structural characteristics as well as in the carbohydrate fermentation profile (Table 4) among the Bacillus species could be attributed to differences in their DNA sequences and possibly in their 16S rRNA genes (sequences available at NCBI data base) thus characterizing each species and differentiating them as strains. However, similarities exist between similar strains.

The observed similarity of the phenotypic, biochemical characteristics of isolate ODS 29 to the Enterobacter species (Tables 2, 3 and 4) and the high similarity of its partial 16S rRNA gene sequence to that of RefSeq for $E$. cloacae suggests it to be Enterobacter cloacae. As such, in consideration of the phenotypic, biochemical and carbohydrate fermentation profile, sequence identity and phylogenetic analysis (Figure 3), the isolate ODS 29 was preliminary identified as $E$. cloacae and based on these data, we assigned our strain as E cloacae strain ODS 29 with the accession number MH879829. Previously, few phytaseproducing Enterobacter species from different soil portions and origins had been isolated and characterized; but until now, information reporting isolation of phytase-producing $E$. cloacae from Nigerian soil is scarce and seems to have been made available for the first time by the authors.

The observation of similarities in the phenotypic and biochemical characteristics of isolates ODS 
25, ODS 33 and FDS 10 to the Bacillus species (Tables 2, 3 and 4) and the high similarity of their partial 16S rRNA gene sequences to that of RefSeq for Bacillus amyloliquefaciens suggests these isolates to be Bacillus amyloliquefaciens. Although these isolates exhibited similar phenotypic and biochemical characteristics, yet there exist differences in the order of their nucleotide bases in the gene studied, causing them to be distinct from each other. This is evident in the phylogenetic relation (Figure 3), revealing a strain variation of the species. Therefore in consideration of their phenotypic, biochemical and carbohydrate fermentation profile, sequence identities and phylogenetic analyses, they were preliminary identified as $B$. amyloliquefaciens and based on these data; they were assigned $B$. amyloliquefaciens strains ODS 25, ODS 33 and FDS 10 with the accession numbers MH879828, MH879830 and MH879831 respectively.

The observation of similarities in the phenotypic and biochemical characteristics of isolates ODS 10 and FDS 16 to the Bacillus species (Tables 2, 3 and 4) and the high similarity of their partial 16S rRNA gene sequences to that of RefSeq for Bacillus subtilis suggests these isolates to be Bacillus subtilis. However, the phylogenetic relation of FDS 16 showed it to be closely related to $B$. amyloliquefaciens DSM 7 (NC 014551.1). This disparity in sequence identity and phylogenetic homology of isolate FDS 16 may be attributed to the slight differences occurring in the genotype of the members of the $B$. subtilis group, possibly due to the presence of particular alleles at specified loci in each organism. The observed disparity agree with the findings of Rooney et. al. (2009) and Kanghae et. al. (2016) who had reported that the $B$. subtilis group is complex, comprising several closely related members which include: $B$. amyloliquefaciens, $B$. subtilis and $B$. licheniformis.

The slight differences in the $B$. subtilis group might thus account for the presence of isolate FDS 16 in the cluster group of $B$. amyloliquefaciens, whereas FDS 16 is genotypically $B$. subtilis. Ash et. al. (1991) and Kanghae et. al. (2016) had reported that phylogenetic analysis of the 16S rRNA genes may fail to distinguish the $B$. subtilis species. Therefore in consideration of the phenotypic, biochemical and carbohydrate fermentation profile, sequence identity together with the phylogenetic analysis, isolates ODS 10 and FDS 16 were preliminary identified as $B$. subtilis and based on these data, they were assigned $B$. subtilis strains ODS 10 and FDS 16 with accession numbers $\mathbf{M H 8 7 9 8 2 7}$ and MH879832 respectively.

The observation of significant differences in quantitatively determined activities of phytase (Figure 4) may be a reflection of the differing abilities of the bacteria to produce phytase. The observed differences in activities of the phytases in comparison with what has been obtained for some strains of Bacillus and Enterobacterspecies reported in literature such as $B$. subtilis DR6, $129-378 \mathrm{mU} / \mathrm{ml}$ (Singh et. al., 2013), B. cereus $300.8-323.9 \mathrm{mU} / \mathrm{ml}$ (Sajidan et. al., 2015), E. cloacae PSB-45, $0.305 \mathrm{U} / \mathrm{ml}$ (Kalsi et. al., 2016) and B. subtilis 55 - $88 \mathrm{U} / \mathrm{ml}$ (Shamna et. al., 2012) may possibly be due to strain difference, the application of optimized culture conditions or an engineered state of strains. The higher activities of extracellular phytase produced by the bacteria under study may possibly be attributed to the soil source from where they were obtained. Soil from sources such as dumpsites which accommodate a wide range of microorganisms and sources which accommodate substrates of an enzyme may likely house microorganisms possessing an efficient ability for the production of the enzyme. As such, the observed higher phytase activities of the isolates under study in the native state over strains earlier reported with lower phytase activities may suggest a potential for their use in biotechnological applications.

\section{Conclusion}

Few members of the phytase-producing $E$. cloacae strains with molecular data have been reported and of these, information reporting isolation and identification of phytaseproducing $E$. cloacae strains from Nigeria soil is scarce and seems to have been made available for the first time by the authors. In addition, $E$. cloacae ODS 29 and the Bacillus isolates showed higher phytase activities than has been observed for some similar strains from other origins. As such, they may be considered as having potential for biotechnological applications, possibly in feed, for the reduction of environmental phosphorus pollution or in the solubilization of organic phosphorus in soil. However, further investigation into the development of the strains for economic considerations both from the environment and feed-conversion point of view is being considered for future study. 


\section{Acknowledgments}

The authors acknowledge the technical assistances of Mrs. P. N. Nwagala and Dr (Mrs.) A. E. Asagbra of the Federal Institute of Industrial Research Oshodi, Lagos, and Dr. A. B. James of the Nigerian Institute of Medical Research, Lagos, Nigeria respectively.

\section{References}

Abd-Alhadi, R., Sumainah, G. and AlBalaa, B. (2015). Production of extracellular phytase from Bacillus subtilis isolated from Syrian soil. Int. J. PharmTech. Res. 8(1): 154-59.

Abdel-Megeed, A. and Tahir, A. (2015). Reduction of phosphorus pollution from broilers waste through supplementation of wheat based broilers feed with phytase. J. Chem. Article ID: 867014. 3pp. Doi.org/10.1155/2015/867014.

Ash, C., Farrow, J.A.E., Dorsch, M., Stackebrandt, E. and Collins, M. D. (1991). Comparative analysis of Bacillus anthracis, Bacillus cereus, and related species on the basis of reverse transcriptase sequencing of $16 \mathrm{~S}$ rRNA. Int. J. Syst. Bacteriol. 41: 343-46.

Blaabjerg, K., Jørgensen, $\mathrm{H}_{\text {., }}$ Tauson, A. H. and Poulsen, H. D. (2011). The presence of inositol phosphates in gastric pig digest is affected by time after feeding a non- fermented or fermented liquid wheat- and barley-based diet. J. Anim. Sci. 89: 3153-62.

Brenner, J. D. and Farmer, J. J. (2001). Family 1. Enterobacteriacea. In: Bergey's Manual of Systematic Bacteriology. $2^{\text {nd }}$ ed. 2: 587-897

Demirkan, E., Baygın, E. and Ustaet, A. (2014). Screening of phytate hydrolysing Bacillus sp. isolated from soil and optimization of the certain nutritional and Physical parameters on the production of phytase. Turk. J. Biochem. 39: 206-14.

Felsenstein, J. (1985). Confidence limits on phylogenies: An approach to using the bootstrap. Evolution 39 (4): 783-91.

Holt, J. G., Krieg, N. R., Sneath, P. H. A., Staley, J.T. and Williams, S. T. (1994). Bergey's manual of determinative bacteriology, 9th ed. Williams \& Wilkins, Baltimore, pp 175-189.
Kalsi, H. K., Singh, R., Dhaliwal, H. S. and Kumar, V. (2016). Phytases from Enterobacter and Serratia Species with desirable characteristics for food and feed applications. 3 Biotech. 6(64). Doi:10.1007/s13205-0160378-x.

Kanghae, A., Monka, J., Eungwanichayapant, P. D., Niamsup P. and Chukeatirote, E. (2016). Characterization of Bacillus species exhibiting strong proteolytic activity isolated from thua nao. Acta Aliment Hung. 45(1): 11-19.

Kimura, M. (1980). A simple method for estimating evolutionary rate of base substitutions through comparative studies of nucleotide sequences. J. Mol. Evol. 16: 111-20.

Kumar, V., Singh, D., Sangwan, P. and Gill, P. K. (2015). Management of environmental phosphorus pollution using phytases: current challenges and future prospects. Applied Environmental Biotechnology: Present Scenario and Future Trends. 97-114.

Logan, N. A, and Vos, P. D. (2009). Genus 1. Bacillus. Cohn 1872 In: (eds) Vos, P. D., Garrity, G., Jones, D., Krieg, N. R., Ludwig, W., Rainey, F. A., Schleifer, K. H. and Whitman, W. B. Bergey's Manual of Systematic Bacteriology, 3: The Firmicutes, Springer, 21-7.

Naves, L. de P., Rodrigues, P. B., Bertechini, A. G., Correa, A. D., de Oliveira, D. H., de Oliveira, E. C., Duarte, W. F. and da Cunha, M. R. R. (2014). Comparison of methodologies to quantify phytate phosphorus in diets containing phytase and excreta from broilers. AsianAustralas. J. Anim. Sci. 27(7): 1003-12. Doi.org/10.5713/ajas.2013.13538.

Onawola, O. O., Asagbra, A. E., Nwagala, P. N., Olatope, S. O. A. and Elemo, G. N. (2016a). Isolation and biochemical characterization of phytase-producing bacteria from top soil of an abbattoir. J. Ind. Res. Technol. 5(2): 65-74.

Onawola, O. O., Nwagala, P. N., Asagbra, A. E., Magaji, B. M., Akinwunmi, O. O., Oladipupo, B. O. and Lawal, A. K. (2016b). Determination of the optimal conditions for activity of phytase from Bacillus subtilis. J. Ind. Res. Technol. 5(2): $53-64$. 
Rooney, A. P., Price, N. P. C., Ehrhardt, J. L., Swezey, J. L. and Bannan, J. D. (2009). Phylogeny and molecular taxonomy of the Bacillus subtilis species complex and description of Bacillus subtilis subsp. inaquosorum subsp. nov. Int. J. Syst. Evol. Micr. 59: 2429-36.

Sajidan, R. W., Sari, E. N., Ratriyanto, A. W. H. and Greiner, R. (2015). Phytase-producing bacteria from extreme regions in Indonesia. Braz. Arch. Biol. Technol. 58(5): 711-17.

Saribuga, E., Hayrunnisa, N., Neslihan D., Merve, S. and Bulent, C. (2014). Purification, characterization of phytase enzyme from Lactobacillus plantarum bacteria and determination of its kinetic properties. Afr. J. Biotechnol. 13(23): 2373-78.

Shamna, K. S., Rajamanikandan, K. C. P., Mukesh, K. D. J., Balakumaran, M. D. and Kalaichelvan, P. T. (2012). Extracellular production of phytases by a native Bacillus subtilis strain. Ann. Biol. Res. 3: 979-87.

Singh, N. K., Joshi, D. K. and Gupta, R. K. (2013). Isolation of phytase producing bacteria and optimization of phytase production parameters. J. Microbiol. 6, e6419. doi:10.5812/jjm.6419.

Tamura, K., Stecher, G., Peterson, D., Filipski, A. and Kumar, S. (2013). Molecular evolutionary genetics analysis. Version 6.0. Mol. Biol. Evol. 30: 2725-29.

Vohra, A., Kaur, P. and Satyanarayana, T. (2010). Production, characteristics and applications of the cell-bound phytase of Pichia anomala. Ant.Van Leeu. 99: 51-5.

Zhang, L., An, L., Gao, X. and Wang, Y. (2010). Properties of $A$. ficuum AS3.324 phytase expressed in tobacco. Process Biochem. 40: 213-16. 